\title{
Rekayasa Perangkat Lunak Sistem Ujian TOEFL Menggunakan PHP \& MySQL Berbasis Framework Codeigniter
}

\author{
Yustiar Alan Dwihana ${ }^{1}$, Achmad Bisri² \\ 1,2Teknik Informatika, Universitas Pamulang \\ Jalan Surya Kencana No. 1, Pamulang, Tangerang Selatan, Banten 15417 \\ yustiar.allan@gmail.com ${ }^{1}$, achmadbizri@gmail.com ${ }^{2}$
}

\begin{abstract}
Nowadays TOEFL score is often used as a requirement by universities that have an international curriculum base in the process of admitting new students and requires all students to understand English as a communication tool in the learning process. A large number of prospective students as examinees and the use of written examinations often results in loss and damage to exam data, plus a process of correction of exam results that takes a long time, causing information from various data to be obtained longer. To overcome this problem, a TOEFL exam system software needs to be made. The flow and stages made in software engineering include requirements planning, software design, and software implementation. The use of PHP and My $S Q L$ based on framework CodeIgniter on the TOEFL exam has provided convenience to an institution or agency, the positive results in its application took the form of time savings of 3,440 minutes or around $92.5 \%$ and reduced stages in the test from 9 stages to only 2 stages. So that the resources, infrastructure, and costs needed in the examination process are reduced.
\end{abstract}

Keywords - Exam, Codeigniter, Software, TOEFL

Abstrak - Saat ini skor TOEFL sering kali dijadikan suatu syarat oleh perguruan tinggi yang memiliki basis kurikulum internasional dalam proses penerimaan mahasiswa baru, serta mewajibkan seluruh mahasiswanya memahami bahasa Inggris sebagai alat komunikasi dalam proses pembelajaran. Banyaknya calon mahasiswa sebagai peserta ujian serta penggunaan ujian tertulis, seringkali mengakibatkan terjadinya kehilangan dan kerusakan data-data ujian, ditambah proses koreksi hasil ujian yang menyita waktu lama, menyebabkan informasi dari berbagai data didapat semakin lama pula. Untuk mengatasi masalah tersebut, perlu dibuat suatu perangkat lunak sistem ujian TOEFL. Alur dan tahapan-tahapan yang dibuat dalam rekayasa perangkat lunak ini meliputi perencanaan syarat, perancangan perangkat lunak, dan implementasi perangkat lunak. Penggunaan PHP dan My SQL berbasis framework codeigniter pada ujian TOEFL ini telah memberikan kemudahan pada suatu lembaga atau instansi, hasil positif dalam penerapanya berupa penghematan waktu sebesar 3.440 menit atau sekitar $\mathbf{9 2 . 5 \%}$ dan berkurangnya tahapan-tahapan dalam ujian dari semula 9 tahapan menjadi hanya 2 tahapan. Sehingga sumber daya, prasarana dan biaya yang dibutuhkan dalam proses ujian berkurang.

Kata Kunci-CodeIgniter, Perangkat Lunak, TOEFL, Ujian.

\section{PENDAHULUAN}

Bahasa Inggris merupakan salah satu bahasa yang paling banyak digunakan diseluruh dunia, terlebih bahasa ini digunakan sebagai alat komunikasi antar bangsa (International Language), sehingga bahasa ini mempunyai peranan yang sangat penting dalam dunia pendidikan maupun dunia kerja. Peranan ini terlihat jelas dengan keberadaan nilai minimum ujian TOEFL sebagai suatu persyaratan penerimaan peserta didik baru atau seleksi calon pegawai dalam suatu instansi / lembaga[1].

Test Of English as a Foreign Language atau yang sering disebut TOEFL, merupakan ujian yang digunakan dalam mengukur kemampuan tingkat bahasa inggris yang dimiliki seseorang. Ujian ini terorganisir oleh suatu lembaga Amerika yang bernama Education Testing Service (ETS), ujian ini diberikan agar dapat memastikan seseorang dalam memahami uraian-uraian kata dan penulisan yang baik dan benar dalam bahasa Inggris, khususnya untuk mahasiswa kemampuan ini sangat penting dalam pembuatan suatu karya ilmiah[2].

Latar belakang masalah dalam penelitian ini berawal saat skor TOEFL dijadikan sebagai persyaratan penerimaan peserta didik baru di Universitas Sampoerna, yang dalam proses pembelajarannya menggunakan bahasa Inggris dan mewajibkan mahasiswanya dapat memahami bahasa Inggris baik lisan maupun tertulis. Banyak dari sebagian dari calon peserta didik baru yang mendaftar untuk berkuliah di Universitas Sampoerna namun belum memiliki skor TOEFL yang di persyaratkan, untuk mempermudah siswa siswi mendapatkan skor yang dipersyaratkan sementara waktu (sebagai tolak ukur penerimaan mahasiswa baru) maka pihak Testing Center Universitas Sampoerna memberikan ujian TOEFL (bersifat simulasi, tanpa adanya biaya administrasi) kepada calon peserta didik baru, ujian ini diberikan agar calon mahasiswa dapat mengetahui kemampuanya dalam bahasa Inggris. Namun dalam pelaksanaan ujian TOEFL, unit kerja Testing Center pada Universitas Sampoerna masih menggunakan sitem ujian TOEFL manual (tertulis), Hal ini menyebabkan proses administrasi dalam proses ujian tidak terorganisir dengan baik dan sering kali terjadinya kerusakan data ujian (seperti lembar soal tercoret dan 
lembar jawab tersobek) ditambah proses koreksi manual membuat laporan hasil ujian semakin lama, menjadikan proses ini jauh dari efisien.

Untuk lebih memudahkan pihak-pihak terkait dan meningkatkan efisiensi waktu dalam pelaksanakan ujian TOEFL pada Universitas Sampoerna, diperlukan suatu sistem yang dapat menyelesaikan permasalahan-permaslahan seperti yang telah disebutkan diatas. Dengan diusulkanya pembuatan sitem ujian TOEFL menggunakan PHP dan My SQL Berbasis Framework Codeigniter diharapkan dapat mengatasi permaslahan serta meminimalisir waktu dan biaya yang dikeluarkan.

\section{METODOLOGI PENELITIAN}

Dalam penelitian ini, data-data yang diperoleh mengunakan beberapa metode seperti data primer dan data sekunder. Data primer merupakan data yang diperoleh secara langsung dari tempat pengamatan atau sumber penelitian, dengan cara pencatatan dari objek terkait penelitian. Teknik yang digunakan untuk mendapatkan data ini bisa dengan cara observasi dan juga wawancara contohnya adalah pengamatan proses ujian dari awal hingga akhir data yang diperoleh berupa laporan hasil ujian dan melakukan wawancara dengan pihak terkait yang dimaksudkan agar data dan kebutuhan dapat yang diperoleh dengan jelas dan lengkap[3]. Sedangkan data sekunder merupakan pengumpulan data dengan menggunakan cara mencari referensi atau penelitian terkait dengan pembahasan yang dihadapi[4].

Perancangan sistem yang digunakan dalam rekayasa perangkat lunak ini adalah mengunakan Rapid Application Developement (RAD) dengan alur sebagai berikut:

1. Perencanaan syarat (Requirements planning)

Dalam tahapan ini peneliti melakukan beberapa aktifitas diantaranya: mempelajari suatu data ujian dan soal serta proses pengoreksian dan menganalisa sistem berjalan saat ini serta merumuskan maslah yang ada untuk dibuat analisa sistem usulan.

2. Perancangan sistem (Workshop design)

Dalam tahapan ini peneliti membuat suatu desain rancangan berdasarkan sistem usulan dan referensi ujian online yang pernah digunakan oleh Universitas Sampoerna, yang bertujuan agar dapat membuat suatu sistem yang menyerupai tanpa mengurangi esensi dalam ujian TOEFL dan meminimalisir masalah yang ada, perancangan dalam rekayasa perangkat lunak ini menggunakan bahasa permodelan UML yang tujuanya agar dapat mudah dipahami secara umum. Dan perancangan basis data menggunakan class diagram, use case untuk menggambarkan hubungkan antar entitas. Tahap akhir yaitu perancangan input dan output, membuat tampilan layar dan pada akhirnya dilakukan suatu konstruksi.

3. Implementasi sistem (Coding and testing)
Setelah dilakukan analisa sistem dan secara terinci maka tahapan berikutnya adalah implementasi sistem, tahapan ini mencakup beberapa aktifitas seperti coding dan testing. Perangkat lunak yang dibuat menggunakan bahasa pemrograman PHP dan My SQL, setelah diimplementasikan, kemudian diuji dengan pengujian black box yang memfokuskan pengujian pada fungsi-fungsi dan keluaran dari sistem dan memastikan sistem yang dibuat dapat digunakan berdasarkan kebutuhan[5].

\section{A. Analisa dan Perancangan Sistem}

Analisa sistem merupakan suatu aktifitas agar dapat melihat sistem berjalan, mengamati hal mana saja yang baik dan tidak baik, melakukan pencatatan dan pendokumentasian suatu kebutuhan yang dapat memenuhi suatu sistem yang baru. Hal tersebut dilihat sederhana namun pada kenyataanya tidak, banyak hambatan dan hal lain yang harus diperhatikan dalam proses ini[6]. Analisa sistem juga dapat didefinisikan suatu penjabaran sistem informasi nyata dan utuh kedalam sebuah bagian dan komponen yang lebih komplek yang memiliki ujuan mengidentifikasi dan mengevaluasi masalah yang timbul. Sehingga diharapkan memberikan suatu solusi berupa perbaikan atau pengembangan ke ranah yang lebih baik lagi[7]. Analisa sistem ini mendapati suatu data dan fakta serta dijadikan bahan-bahan dalam pengujian dan analisa untuk dapat dikembangkan dalam suatu perangkat lunak usulan[].

\section{B. Analisa Sistem Berjalan}

Berawal dari penetapan standar skor TOEFL sebagai syarat penerimaan penerimaan mahasiswa baru Universitas Sampoerna, bagian akademik penerimaan mahasiswa baru mengumpulkan data yang akan diikutsertakan, dalam ujian bahasa Inggris melewati ujian TOEFL simulasi. Data ujian yang terkumpul diberikan kepada pihak Testing Center guna dilakukan penjadwalan ujian. Setelah Jadwal ujian dibuat, tim dari unit kerja Testing center melakukan prasarana mulai pemilihan soal yang ditentukan dari buku TOEFL oleh Native, pembuatan master soal dan lembar jawab oleh staf Testing center hingga proses penyalinan soal dan lembar jawab yang disesuaikan dengan banyaknya jumlah peserta peserta. Setelah paket soal yang sudah dibuat dapat dibagikan kepada peserta ujian yang datang pada saat ujian berlangsung, hingga pengumpulan data hasil ujian, Native melakukan koreksi hasil ujian dan merekap seluruh data nilai peserta, nilai yang sudah terangkum hingga diberikan kepada staf Testing Center agar selanjutnya di proses menjadi skor akhir dalam dokumen excel untuk kemudian di cetak. Kemudian hasil tersebut diserahkan ke bagian akademik penerimaan siswa baru untuk dibagikan. Dari proses ujian ini diperoleh sebuah klasifikasi peserta apakah layak mengikuti perkuliahan di Universitas Sampoerna dengan skor yang sudah ada atau harus menjalani sebuah pelatihan khusus untuk dapat mengikuti ujian TOEFL Internasional sebagaimana sertifikat yang dipersyaratkan. Sehubungan dengan hasil 
Observasi dan wawancara secara langsgung dengan pihak Testing Center Universitas Sampoerna, maka peneliti dapat menggambarkan sistem berjalan pada Universitas Sampoerna melalui aktifitas diagram sebagai berikut:

1. Diagram aktifitas permintaan ujian

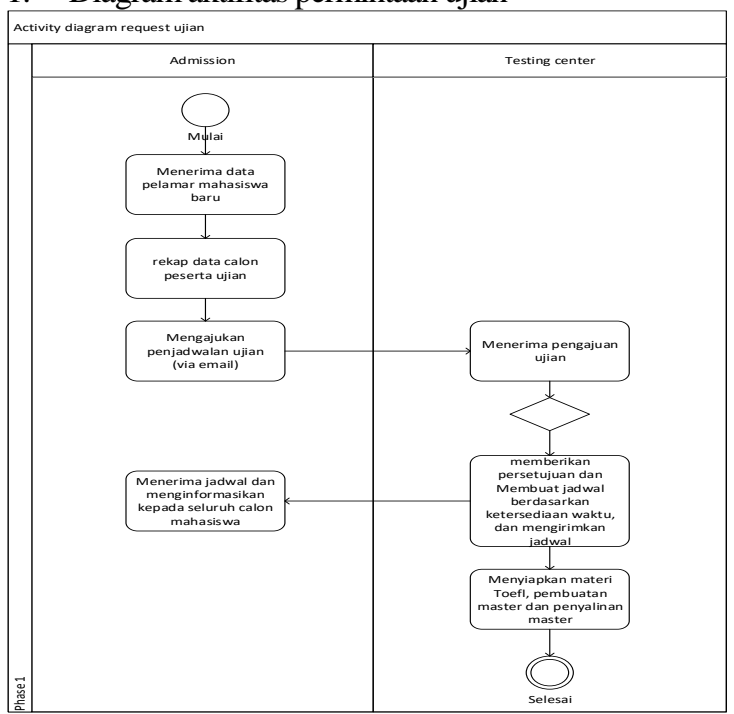

Gambar 1. Diagram Aktifitas Permintaan Penjadwalan Ujian Pada Sistem Berjalan

\section{Diagram Aktifitas Proses Ujian}

Gambar di bawah menjelaskan proses ujian yaitu dimulai ketika bagian akademik penerimaaan siswa baru menginformasikan jadwal ujian kepada mahasiswa (peserta ujian). Pesertam melakukan ujian sesuai jadwal yang dikirim oleh Admission, setelah ujian selesai, testing center mengumpulan soal ujian dan data ujian untuk diolah.

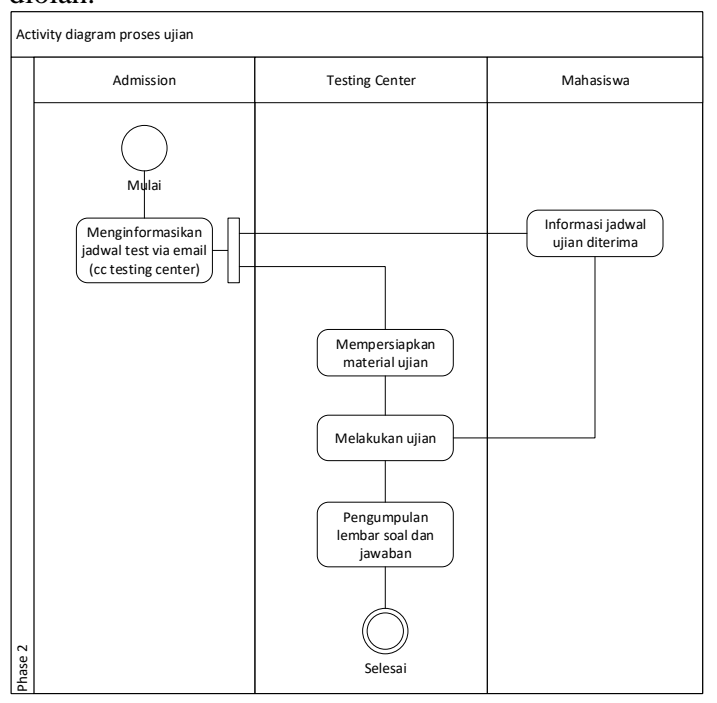

Gambar 2. Diagram Aktifitas Melakukan Proses Ujian Pada Sistem Berjalan (Proses Ujian Berlangsung)

3. Diagram Aktifitas Pembuatan Laporan (Actifity diagram of reporting)
Gambar di bawah menjelaskan laporan ujian yang dapat diterima oleh peserta ujian TOEFL setelah melewati rangkaian panjang yang disebutkan dalam sistem berjalan

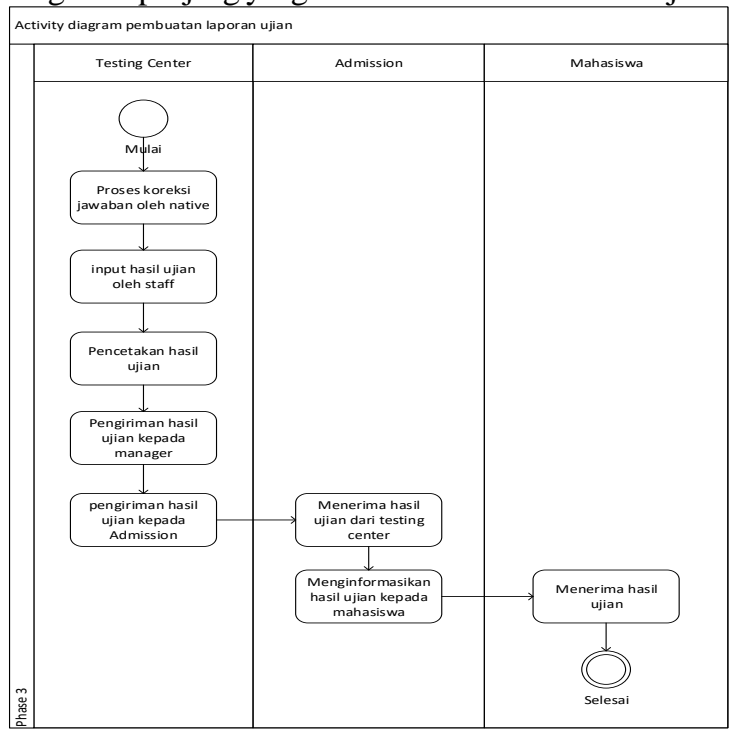

Gambar 3. Diagram aktifitas pembuatan laporan ujian pada sistem berjalan

\section{Analisa Sistem Usulan}

Analisa sistem usulan disarankan agar menyesuaikan kebutuhan yang ada dengan berdasarkan identifikasi masalah dan batasan masalah, agar disesuaikan dengan pemecahan masalah berdasarkan kondisi suatu sistem yang akan dibangun. UML yang berisi beberapa diagram seperti: usecase diagram, activity diagram, sequence diagram dan class diagram. Serta perancangan basis data yang berisikan ERD, transformasi ERD ke LRS, LRS, dan perancangan interface [8].

\section{Use Case Diagram}

Gambar use case dibawah ini menjelaskan mengenai hak akses masing-masing pengguna dalam pengelolaan menu pada sistem usulan.

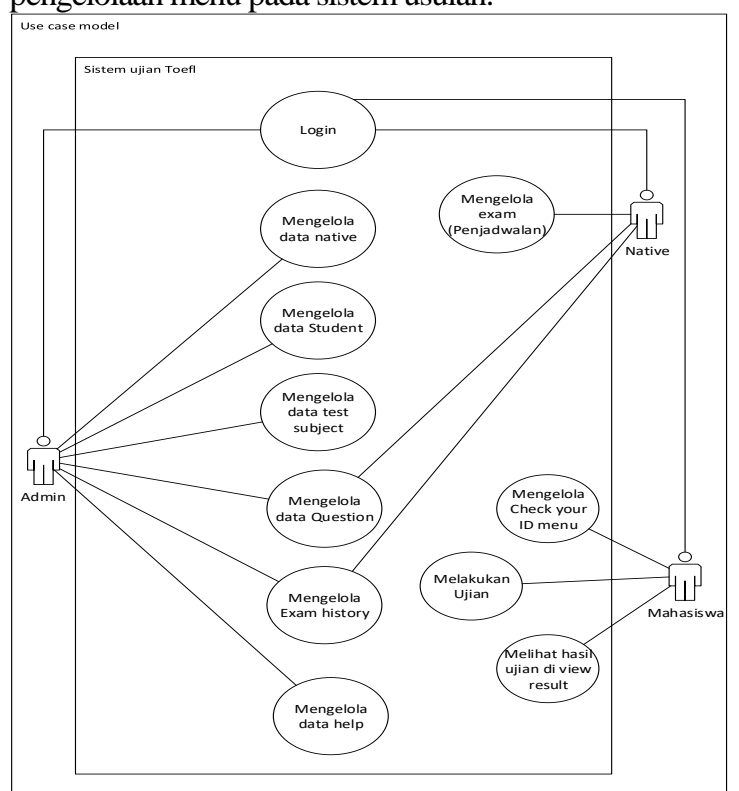

Gambar 4. Use Case Diagram Sistem Usulan 


\section{Activity Diagram}

Activity diagram dibawah ini menjelaskan proses ujian yang dilakukan oleh peserta.

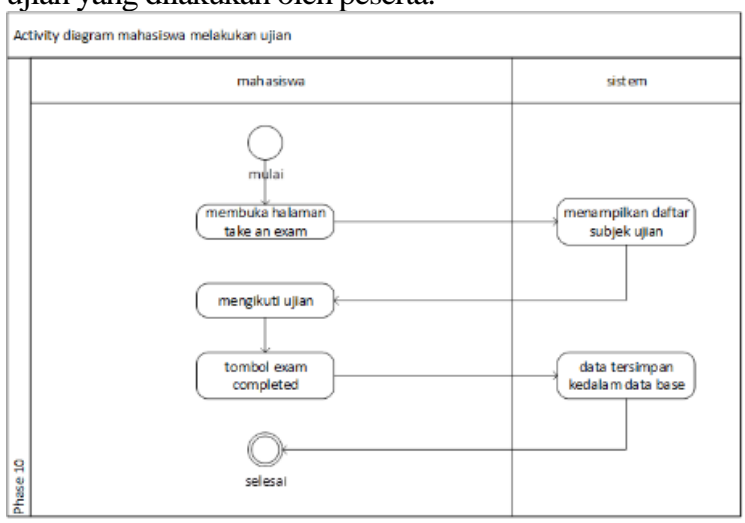

Gambar 5. Activity Diagram Melakukan Ujian

\section{Sequence Diagram}

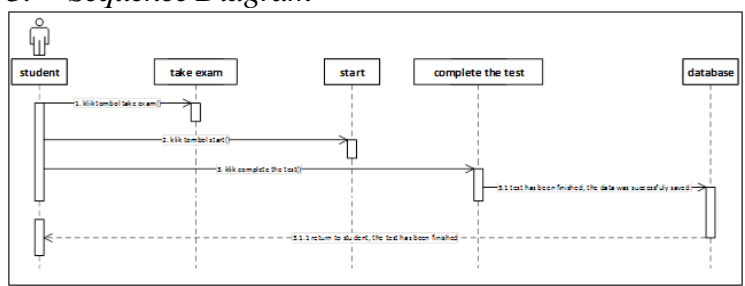

Gambar 6. Sequence Diagram Take an Exam

Sequence diagram diatas menjelaskan proses ujian yang dilakukan oleh peserta menggunakan sistem usulan.

\section{Class Diagram}

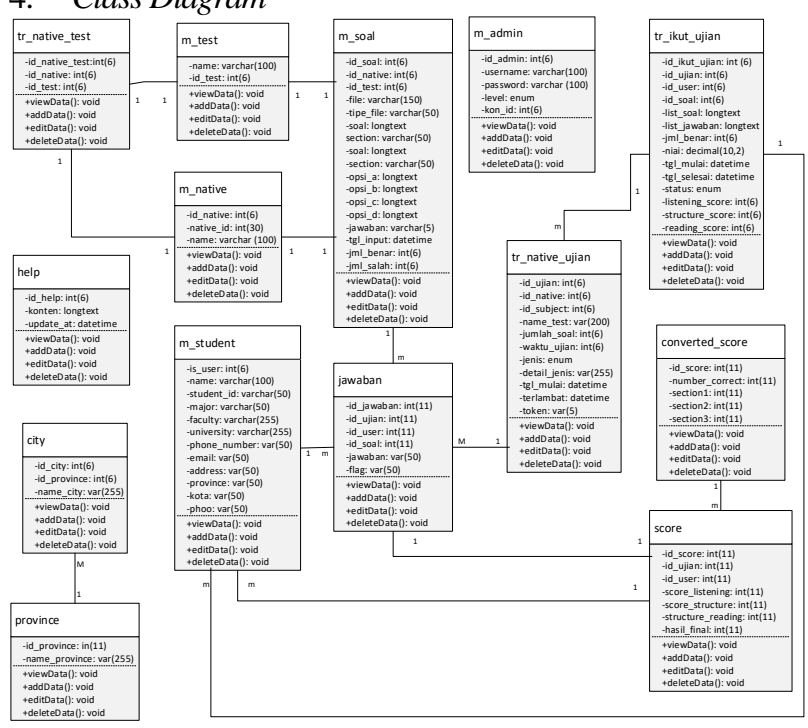

Gambar 7. Class Diagram

Dalam diagram kelas sistem yang diusulkan terdapat 14 kelas yaitu: kelas tr_native_test, m_test, m_native, m_soal, m_admin, jawaban, tr_ikut_ujian, tr_native_ujian, score, converted_score.

D. Perancangan Basis Data

1. Entity Relation Diagram (ERD)

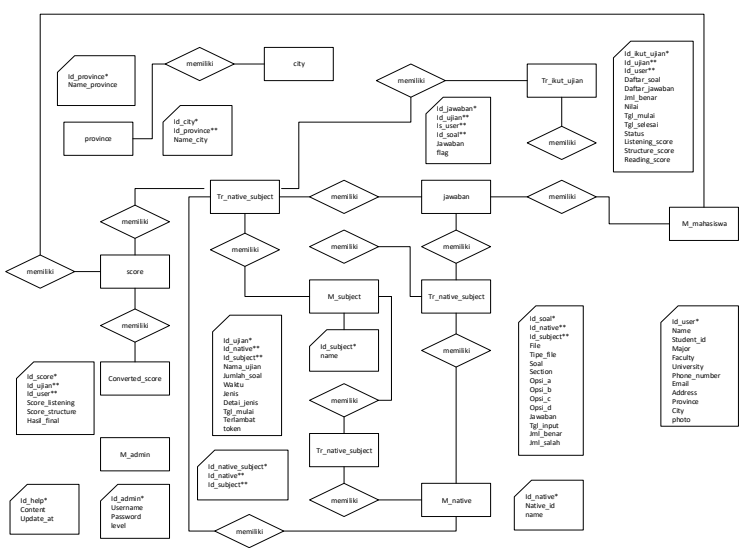

Gambar 8. Entity Diagram Relationship

Dalam pembuatan ERD berfugsi untuk merancang suatu model dasar struktur data dan juga hubungan dari tiap-tiap data tersebut dan mempermudah dalam mengembangkan suatu sistem ujian[9].

\section{Transformasi ERD ke LRS}

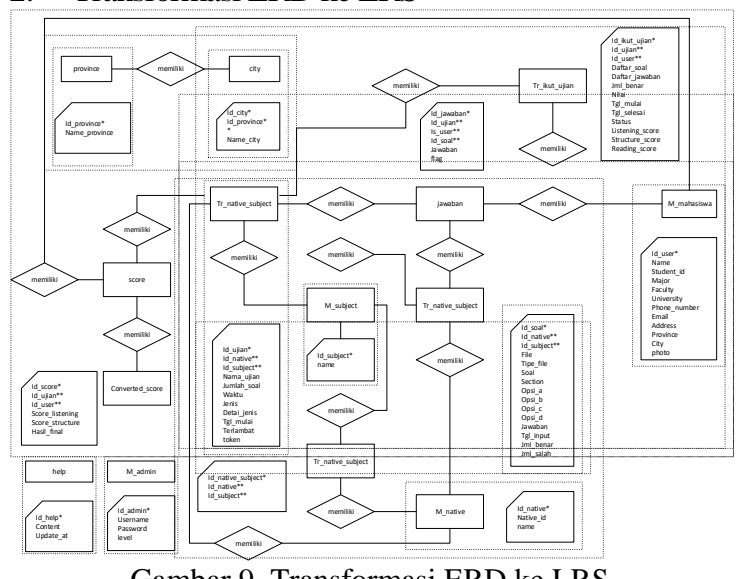

Gambar 9. Transformasi ERD ke LRS

3. Logical Record Structure (LRS)

Setelah ditransformasikan, maka bentuk dari Logical Record Structur dalam sistem yang di usulkan akan terbentuk seperti gambar dibawah ini:

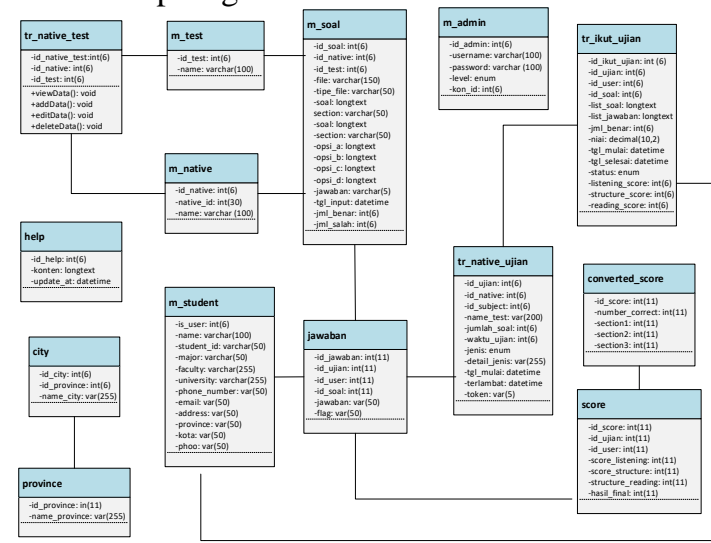

Gambar 10. Logical Relation Structure

E. Perancangan Antar Muka (User Interface)

Halaman login pada sistem usulan ini dibuat dengan sederhana, sebagaimana layakna form login pada 
umumnya, dibuat agar memungkinkan semua kategori pengguna dapat melakukan login sistem dihalaman yang sama

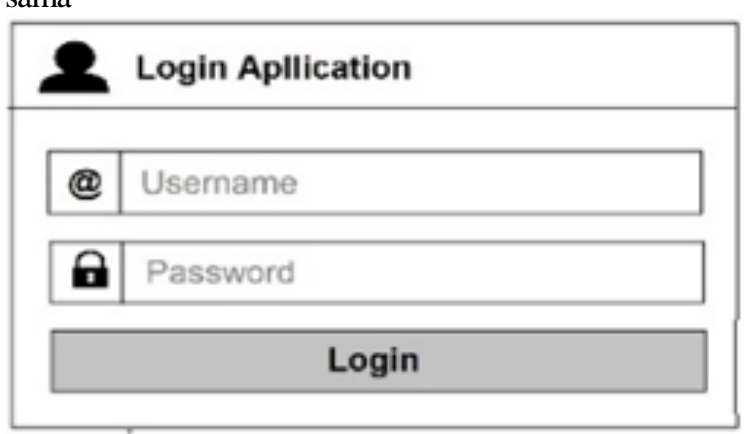

Gambar 11. Form Login Semua Kategori Pengguna

Halaman student data ini dibuat agar memungkinkan admin dapat meginput data pengguna peserta atau mahasiswa.

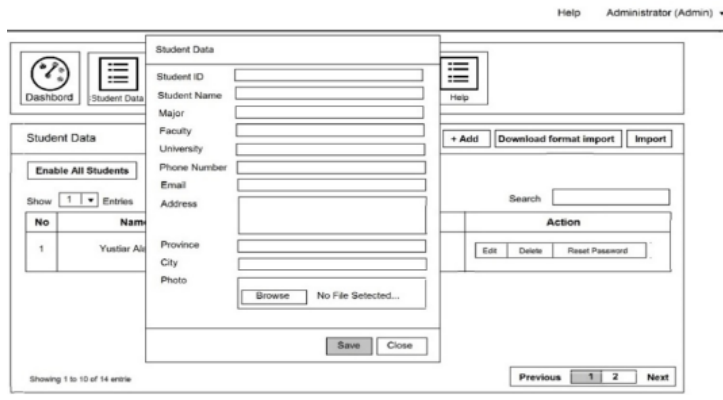

Gambar 12. Halaman Input Data Pesrta Ujian

Halaman Native data seperti gambar dibawah ini dibuat agar memungkinkan admin dapat menginput data kategori native.

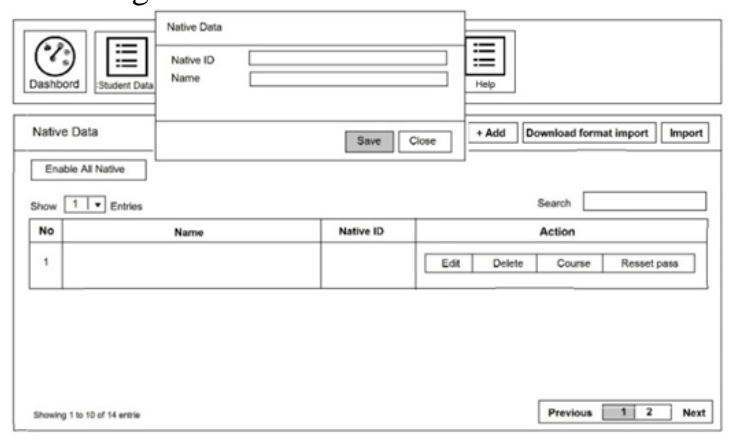

Gambar 13. Halaman Input Native

Halaman input dapat soal ini dibuat agar memungkinkan pengguna dengan kategori admin dan native melakukan penginputan data soal dengan cepat dan mudah, halaman ini terdapat dalam menu Question yang terdapat di dalam kategori pengguna admin dan juga native.

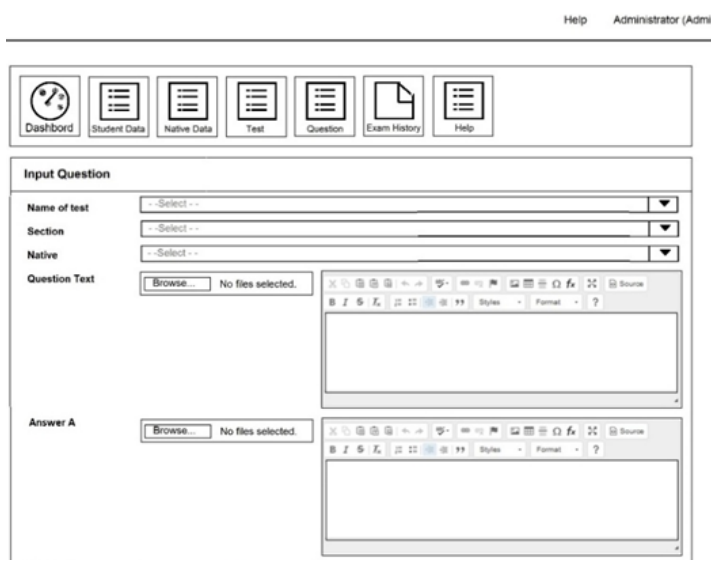

Gambar 14. Halaman Input Pertanyaan

Halaman Create an Exam ini dibuat agar memungkinkan native dapat membuat jadwal pelaksanaan ujian, dengan adanya form ini, pengguna dapat menentukan waktu pelaksanaan ujian TOEFL.

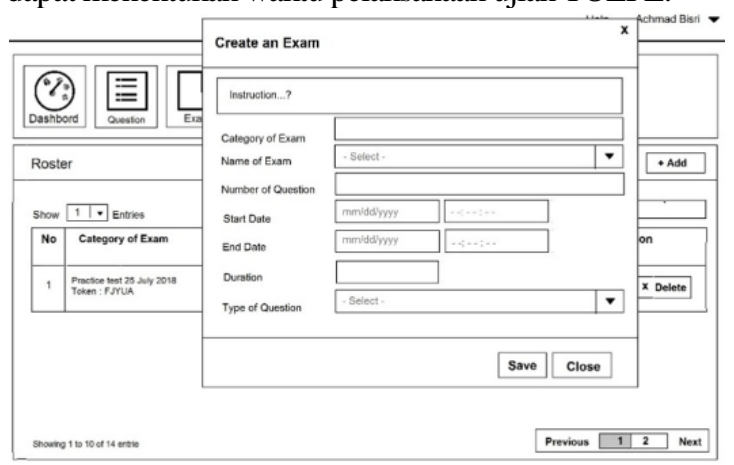

Gambar 15. Halaman Penjadwalan Ujian

Halaman/ layout dibawah ini adalah sebuah rancangan antar muka untuk tampilan soal pada saat ujian berlangsung.

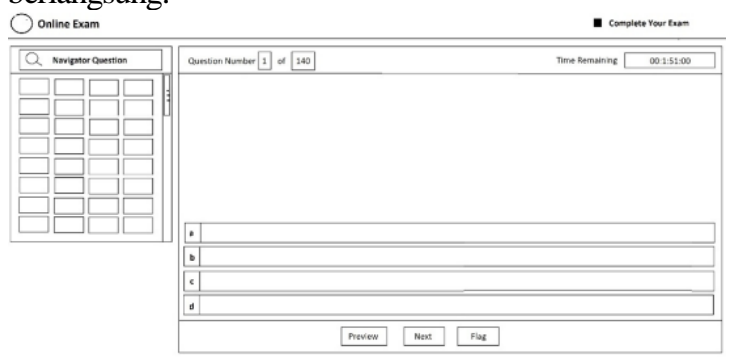

Gambar 16. Halaman Soal

Dibawah ini merupakan rancangan antar muka untuk tampilan hasil laporan ujian yang dapat dilihat oleh peserta, tampilan ini dibuat agar memungkinkan peserta dapat melihat skor dan dapat mencetak secara langsung. 


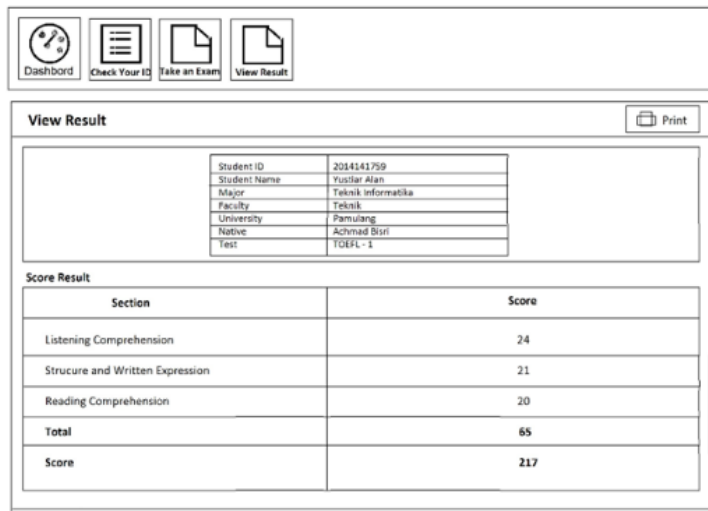

Gambar 17. Tampilan Laporan Hasil Ujian

\section{HASIL DAN PEMBAHASAN}

A. Spesifikasi Perangkat Keras (Hardware)

Spesifikasi perangkat keras yang digunakan untuk menjalankan sistem ujian TOEFL adalah Laptop SONY VAIO yang mempunyai detail spesifikasi:

1. Processor (R) Core(TM) i5-33178, @ $1.70 \mathrm{GHz}$

2. System type 64-bit OS, X64-based processor

3. Memory RAM 4 GB

B. Spesifikasi Perangkat Lunak

Perangkat lunak yang dapat digunakan untuk mengakses sistem ujian TOEFL seperti: Windows 8.1 Singgle Language 64bit, Mozila Firefox, XAMPP Server, Notepad++, Framework Codeigniter.

\section{Implementasi Perangkat Lunak}

Implementasi perangkat lunak merupakan tahapan terakhir dimana perangkat lunak yang telah dibuat dapat dioperasikan pada keadaan sebenarnya, sehingga dapat diketahui perangkat lunak yang dibuat benar-benar menghasilkan tujuan yang diinginkan oleh penulis[10]. Implementasi antar muka yang dilakukan adalah dengan memberikan tampilan-tampilan program yang dibuat[11]. Hasil dari perancangan sistem ujian TOEFL yang sudah dibuat kemudian diimplementasikan seperti gambar dibawah ini:

\section{Login Application}

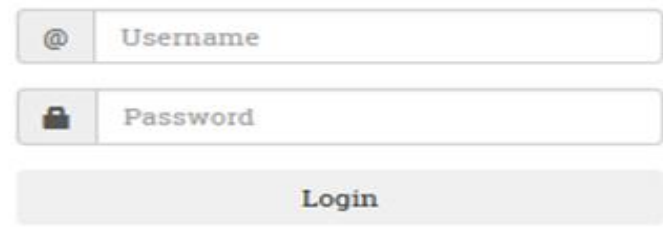

Gambar 18. Form Login (Semua Pengguna)

Form login pada rekayasa perangkat lunak sistem ujian TOEFL pada gambar diatas ini dibuat dengan sederhana yang memungkinkan semua pengguna dapat melakukan login sistem dalam satu halaman yang sama.

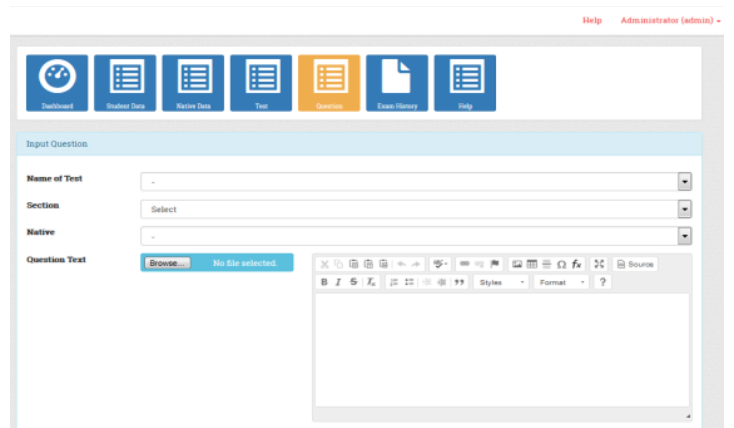

Gambar 19. Form Input Soal

Form input soal diatas berfungsi agar pengguna (admin, native) dapat menginputkan soal-soal dan kunci jawaban dengan mudah, cepat dan tepat.

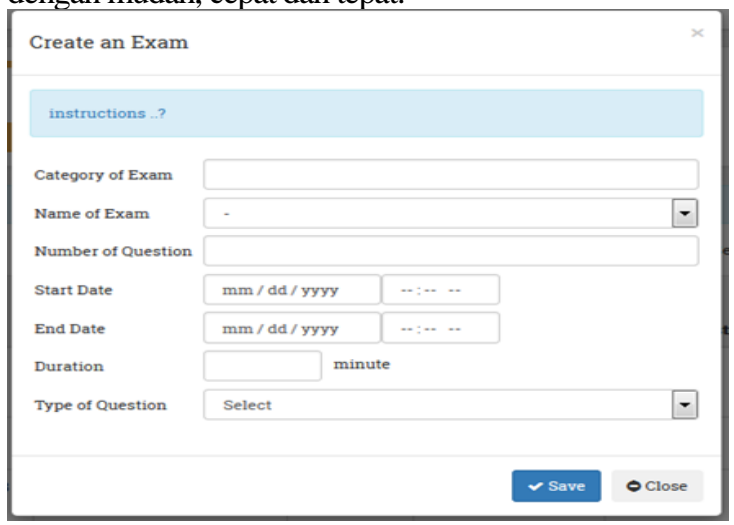

Gambar 20. Form Create an Exam (Penjadwalan)

Form create an exam seperti gambar diatas berfungsi agar native selaku pengawas ujian TOEFL dapat menjadwalkan (menentukan waktu suatu ujian TOEFL).

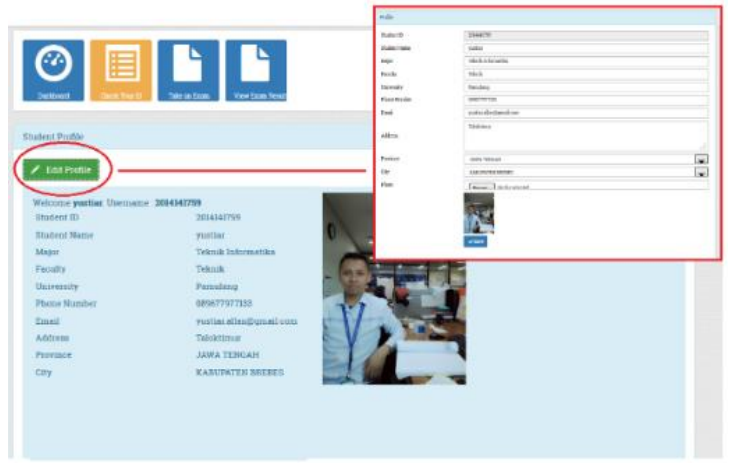

Gambar 21. Form Edit Profil

Halaman/ form edit profil berfungsi untuk peserta ujian agar dapat melengkapi data diri yang diperlukan oleh pihak instansi. 


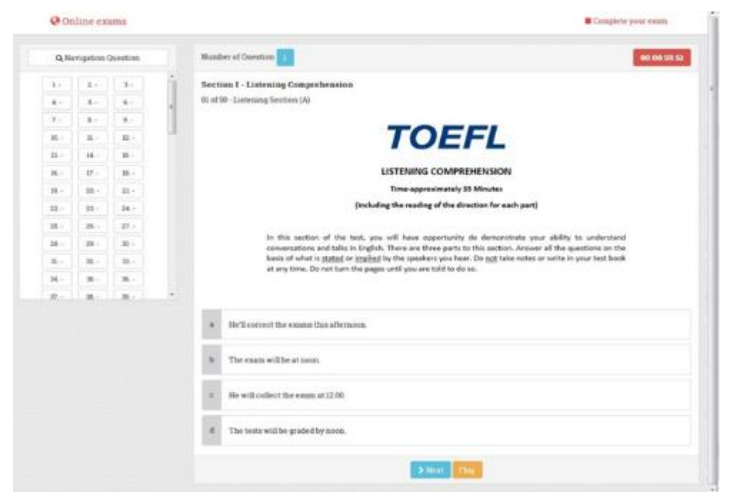

Gambar 22. Tampilan Pada Saat Ujian Berlangsung

Gambar diatas merupakan tampilan antar muka pada saat ujian berlangsung, pengguna (pseserta ujian) dapat menjawab dengan menekan tombol pilihan ganda dari A hingga $\mathrm{D}$, dalam halaman ini dilengkapi juga tombol navigasi yang dapat memudahkan pengguna dapat melewati pertanyaan yang dirasa susah.

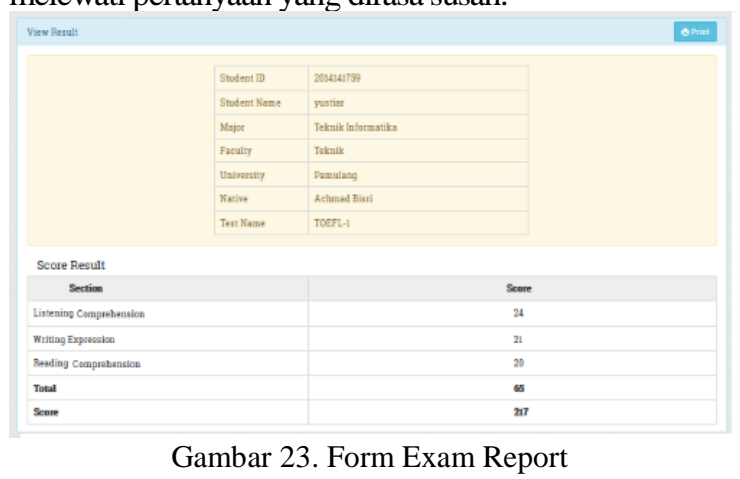

Form Exam Report adalah suatu halaman yang memuat hasil ujian peserta, dalam halaman tersebut terdapat suatu aksi yang dapat digunakan oleh peserta ujian yaitu print guna untuk mencetak hasil ujian. Siswa tidak lagi mennggu lama hasil ujian karena dapat dicetak setelah ujian berlangsung.

\section{Pengujian}

Pengujian perangkat lunak merupakan elemen yang harus dilakukan setelah perangkat lunak diimplementasikan, elemen ini ditujukan guna mengetahui apakah perangkat yang diimplementasikan dapat berjalan sebagaimana mestinya[12]. Pengujian fungsionalitas perangkat lunak sistem ujian TOEFL ini menggunakan metode yaitu black box test, dan dilakukan juga uji penerapan perangkat lunak TOEFL guna untuk mengetahui apakah dapat meningkatkan efisiensi dalam suatu proses ujian TOEFL atau tidak. Dari uji black box dan penerapan didapat suatu hasil data perbandingan sebagai berikut:

Tabel 1. Pengujian black box pada sistem ujian TOEFL

\begin{tabular}{|c|l|l|c|}
\hline Kelas Uji & Prosedur & \multicolumn{1}{|c|}{ Hasil } & Ket. \\
\hline Login & $\begin{array}{l}\text { Mahasiswa } \\
\text { memasukan } \\
\text { username } \\
\text { dan }\end{array}$ & $\begin{array}{l}\text { Mahasiswa } \\
\text { masuk ke } \\
\text { halaman } \\
\text { dashboard }\end{array}$ & $\checkmark$ \\
\hline
\end{tabular}

\begin{tabular}{|c|c|c|c|}
\hline & $\begin{array}{l}\text { password di } \\
\text { form login }\end{array}$ & & \\
\hline Edit Profile & $\begin{array}{l}\text { Klik menu } \\
\text { check your } \\
\text { ID, klik edit } \\
\text { profil, ubah } \\
\text { data dan } \\
\text { save }\end{array}$ & $\begin{array}{l}\text { Data Profil } \\
\text { berubah, } \\
\text { tersimpan di } \\
\text { database }\end{array}$ & $\checkmark$ \\
\hline Take Exam & $\begin{array}{l}\text { Klik menu } \\
\text { take an } \\
\text { exam, klik } \\
\text { start exam, } \\
\text { masukan } \\
\text { token dan } \\
\text { kerjakan } \\
\text { soal, klik } \\
\text { stop untuk } \\
\text { mengakhiri } \\
\text { ujian. }\end{array}$ & $\begin{array}{l}\text { Ujian } \\
\text { berhasil } \\
\text { dilakukan, } \\
\text { data } \\
\text { tersimpan } \\
\text { didatabase, } \\
\text { peserta } \\
\text { dialihkan ke } \\
\text { halaman } \\
\text { hasil. }\end{array}$ & $\checkmark$ \\
\hline View Result & $\begin{array}{l}\text { Klik menu } \\
\text { exam result, } \\
\text { klik view, } \\
\text { klik print }\end{array}$ & $\begin{array}{l}\text { Data nilai } \\
\text { TOEFL } \\
\text { ditampilkan, } \\
\text { dialihkan ke } \\
\text { halaman } \\
\text { print, } \\
\text { berhasilterce } \\
\text { tak }\end{array}$ & $\checkmark$ \\
\hline
\end{tabular}

Keterangan: Tanda " $\checkmark$ " dalam tabel diatas diartikan "berhasil".

Pengujian blackbox adalah Pengujian fungsionalitas perangkat yang memfokuskan pada hasil eksekusi mealui data uji[13]. Pengujian diatas adalah untuk kategori pengguna mahasiswa (pesrta ujian selaku pengguna utama). Tujuan dari pengujian ini adalah untuk mengetahui apakah aplikasi dapat berjalan sesuai harapan atau tidak utamanya dari segi pengguna kategori mahasiswa[14].

Tabel 2. Perbandingan waktu ujian dua tipe yaitu manual tertulis dan menggunakan sistem ujian TOEFL

\begin{tabular}{|c|c|c|}
\hline Proses Tahapan Ujian TOEFL & Tertulis & Sistem \\
\hline Pembuatan soal ujian & 600 & 120 \\
\hline Pembuatan kunci jawaban & 30 & - \\
\hline Pengisian bukti kehadiran & 15 & - \\
\hline Pembagian soal ke peserta & 5 & - \\
\hline Pengerjaan soal ujian & 180 & 160 \\
\hline Pengumpulan soal & 5 & - \\
\hline Pengumpulan jawaban hasil ujian & 5 & - \\
\hline Proses koreksi & 1.440 & - \\
\hline Pembagian hasil ujian & 1.440 & - \\
\hline Total waktu yang dibutuhkan & 3.720 & 280 \\
\hline Waktu yang dihemat & & 3.440 \\
\hline
\end{tabular}

Keterangan: waktu yang tertera dalam bentuk angka pada tabel diatas menggunakan satuan menit.

Uji penerapan merupakan suatu upaya menempatkan hasil rekayasa perangkat ke dunia nyata, dimana perangkat yang diterapkan diharapkan mampu menjawab permaslahan yang ada, serta memastikan bahwa perangkat yang dibuat 
adalah sesuai dengan kebutuhan pengguna [15]. Tabel diatas menjelaskan perbandingan waktu yang dibutuhkan dalam ujian TOEFL dengan menggunakan kedua tipe yaitu manual tertulis dan penggunaan sistem, dengan rincian sebagai berikut: 1. Ujian TOEFL Menggunakan Tipe Tertulis

Penggunaan tipe ini memiliki proses yang cukup panjang dalam suatu pelaksanaan ujian TOEFL yaitu sejumlah 9 tahapan/ proses dan menghabiskan waktu sebanyak 3.720 menit

2. Ujian TOEFL Menggunakan Sistem

Penggunaan sistem dalam suatu ujian TOEFL melibatkan 2 proses yaitu pembuatan soal dan pengerjaan soal ujian itu sendiri dengan total waktu yang dibutuhkan sejumlah 280 menit, dalam tahapan yang di isi tanda "-" dalam tabel diatas dilakukan secara otomatis oleh sistem ujian TOEFL menggunakan PHP dan MySQL berbasis framework CodeIgniter.

Jika keduanya diperbandingkan maka penggunaan sistem jelas lebih menguntungkan, waktu yang dihemat sebesar 3.440 menit, dengan penghematan waktu tersebut maka secara otomatis tahapan dalam ujian serta tenaga, prasarana yang dibutuhkan juga berkurang.

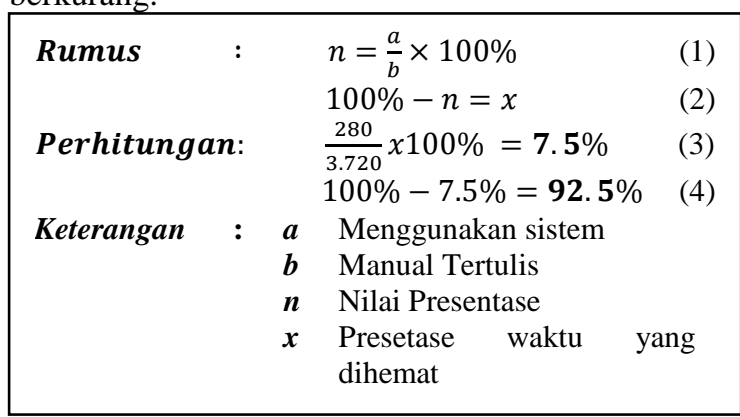

Perhitungan diatas merupakan jumlah presentase waktu yang dihemat berdasarkan tabel perbandingan

\section{KESIMPULAN DAN SARAN}

\section{A. Kesimpulan}

Rekayasa perangkat lunak sistem ujian TOEFL ini dibuat untuk memudahkan instansi/ lembaga dalam melaksanakan ujian TOEFL, fungsi-fungsi didalamnya telah berjalan dan mengeluarkan keluaran yang sesuai dengan yang diharapkan, hal ini dibuktikan dalam suatu pengujian fungsionalitas menggunakan pengujian black box. Dengan penggunaan sistem ujian TOEFL, tahapan dalam proses berkurang dan waktu yang dihemat lebih banyak yaitu sebesar $92.5 \%$, secara otomatis prasarana, tenaga dan biaya yang dikeluarkan jauh lebih sedikit.

\section{B. Saran}

Perangkat lunak sistem ujian TOEFL ini dirancang sangat sederhana, baik dari tampilan, fitur, dan aspek lainya. Maka dari itu penulis berharap agar dilakukan suatu pengembangan dan perawatan, sehingga menjadikan sistem Ujian TOEFL yang sempurna dan lebih baik lagi.

\section{REFERENSI}

[1] Princeton Review (2017). Most Popular Tets Prep Company Tracking The TOEFL 2016 Edition. New York, USA

[2] Kaplan (2007). Cracking the TOEFL 2016-17 Edition, Better Strategies Higher Scores. New York, USA

[3] Retno Wijaya, S. Kom., (2018). Rancang Bangun Sistem Informasi Monitoring Produksi dan Kegiatan Antar Divisi Pada PT. Argo Pantes Tbk. Banten, Indonesia

[4] Ahmad Rijal, S. Kom., (2010). Sistem Akademik Berbasis Web Pada MTS Almunawar. Banten, Indonesia

[5] Hery Setyawan, S. Kom., (2013). Sitem Informasi Akademik Berbasis Web SMA Negeri 1 Bandar Menggunakan PHP dan MySQL. Tangerang, Banten

[6] Nigel Mcfarlane (2003). Rapid Application Development with Mozilla. New York, USA

[7] Arrens (2006). Analisa Sistem. Jakarta, Indonesia

[8] Rudi Sariyanto (2012). Analisis dan Perancangan Aplikasi E-Learning Berbasis Web Pada SMP Negri 35 Surabaya. Surabaya, Indonesia

[9] Tristy Meinawati (2015). Perancangan Aplikais Ujian Online Jurusan Sistem Komputer Universitas Diponegoro. Semarang, Indonesia

[10] Elisa (2014). Rancang Bangun Sistem Informasi Jadwal Perkuliahan Berbasis Jquerry Mobile Dengan Mengggunakan PHP dan My SQL. Purwakarta, Indonesia

[11] Steve McConnell (2011). Rapid Development Training Wild Software Schedule. New York, USA

[12] Mohd. Ehmer Khan (2012). A Comparative Study of White Box, Black Box and Grey Box Testing Techniques. Rajasthan, India

[13] Neetu Dhinga (2014). Contingent study of Black Box and White Box Testing Techniques. Haryana, India

[14] Paramjeet Kaur (2007). A Research Paper on White Box Testing. Punjab, India

[15] Princeton Review (2017). Evaluasi Program Martikulasi "TOEFL" Mahasiswa Universitas Al Azhar Indonesia 2010/2011. Jakarta, Indonesia 